\title{
Front Matter: Volume 6579
}

, "Front Matter: Volume 6579," Proc. SPIE 6579, Mobile Multimedia/Image Processing for Military and Security Applications 2007, 657901 (22 May 2007); doi: 10.1117/12.741638

SPIE Event: Defense and Security Symposium, 2007, Orlando, Florida, United SPIE. States 


\section{PROCEEDINGS OF SPIE}

\section{Mobile Multimedia/Image Processing for Military and Security Applications 2007}

Sos S. Agaian

Sabah A. Jassim

Editors

11-12 April 2007

Orlando, Florida, USA

Sponsored and Published by

SPIE-The International Society for Optical Engineers

Volume 6579

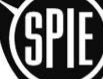

The International Society for Optical Engineering

Proceedings of SPIE-The International Society for Optical Engineering, 9780819467010, v. 6579

SPIE is an international technical society dedicated to advancing engineering and scientific applications of optical, photonic, imaging, electronic, and optoelectronic technologies. 
The papers included in this volume were part of the technical conference cited on the cover and title page. Papers were selected and subject to review by the editors and conference program committee. Some conference presentations may not be available for publication. The papers published in these proceedings reflect the work and thoughts of the authors and are published herein as submitted. The publisher is not responsible for the validity of the information or for any outcomes resulting from reliance thereon.

Please use the following format to cite material from this book:

Author(s), "Title of Paper," in Mobile Multimedia/Image Processing for Military and Security Applications 2007, edited by Sos S. Agaian, Sabah A. Jassim, Proceedings of SPIE Vol. 6579 (SPIE, Bellingham, WA, 2007) Article CID Number.

ISSN 0277-786X

ISBN 9780819467010

Published by

SPIE-The International Society for Optical Engineering

P.O. Box 10, Bellingham, Washington 98227-0010 USA

Telephone 1 360/676-3290 (Pacific Time) · Fax 1 360/647-1445

http://www.spie.org

Copyright (C) 2007, The Society of Photo-Optical Instrumentation Engineers

Copying of material in this book for internal or personal use, or for the internal or personal use of specific clients, beyond the fair use provisions granted by the U.S. Copyright Law is authorized by SPIE subject to payment of copying fees. The Transactional Reporting Service base fee for this volume is $\$ 18.00$ per article (or portion thereof), which should be paid directly to the Copyright Clearance Center (CCC), 222 Rosewood Drive, Danvers, MA 01923. Payment may also be made electronically through CCC Online at http://www.copyright.com. Other copying for republication, resale, advertising or promotion, or any form of systematic or multiple reproduction of any material in this book is prohibited except with permission in writing from the publisher. The CCC fee code is 0277 $786 \times / 07 / \$ 18.00$.

Printed in the United States of America. 


\section{Contents}

vii Conference Committee

\section{SESSION 1 IMAGE/VIDEO COMPRESSION}

657902 Recent advances in multiview distributed video coding [6579-01]

F. Dufaux, M. Ouaret, T. Ebrahimi, École Polytechnique Fédérale de Lausanne (Switzerland)

657903 Memory-efficient contour-based region-of-interest coding of arbitrarily large images [6579-02]

N. G. Sadaka, Arizona State Univ. (USA); G. P. Abousleman, General Dynamics C4 Systems

(USA); L. J. Karam, Arizona State Univ. (USA)

657904 Super-resolution-based enhancement for real-time ultra-low-bit-rate video coding [6579-03]

W.-J. Chien, Arizona State Univ. (USA); G. P. Abousleman, General Dynamics C4 Systems

(USA); L. J. Karam, Arizona State Univ. (USA)

657905 Signal compression via coordinate logic transforms [6579-04]

E. E. Danahy, K. A. Panetta, Tufts Univ. (USA); S. S. Agaian, Univ. of Texas at San Antonio (USA)

\section{SESSION 2 NETWORK ISSUES}

657907 A prompt information retrieval system on handheld devices [6579-06]

Y.-P. Huang, W. Yen, S.-H. Lin, Tatung Univ. (Taiwan)

657909 Detecting and isolating malicious nodes in wireless ad hoc networks [6579-08]

F. Li, S. Jassim, Univ. of Buckingham (United Kingdom)

65790A Impact on routers performance to classify and condition real-time interactive multimedia traffic based on its PHB [6579-34]

S. Alsharif, M. Al-Khatib, Y. Tung, Univ. of South Alabama (USA)

Pagination: Proceedings of SPIE follow an e-First publication model, with papers published first online and then in print and on CD-ROM. Papers are published as they are submitted and meet publication criteria. A unique, consistent, permanent citation identifier (CID) number is assigned to each article at the time of the first publication. Utilization of CIDs allows articles to be fully citable as soon they are published online, and connects the same identifier to all online, print, and electronic versions of the publication.

SPIE uses a six-digit CID article numbering system in which:

- The first four digits correspond to the SPIE volume number.

- The last two digits indicate publication order within the volume using a Base 36 numbering system employing both numerals and letters. These two-number sets start with 00, 01, 02, 03, 04, 05, 06, 07, 08, 09, 0A, 0B ... 0Z, followed by 10-1Z, 20-2Z, etc.

The CID number appears on each page of the manuscript. The complete citation is used on the first page, and an abbreviated version on subsequent pages. 
65790C Switching theory-based steganographic system for JPEG images [6579-11]

R. C. Cherukuri, S. S. Agaian, Univ. of Texas at San Antonio (USA)

65790D New quantization matrices for JPEG steganography [6579-12]

Y. O. Yildiz, K. Panetta, Tufts Univ. (USA); S. Agaian, The Univ. of Texas at San Antonio (USA)

65790E Steganography anomaly detection using simple one-class classification [6579-15]

B. M. Rodriguez, G. L. Peterson, Air Force Institute of Technology (USA);

S. S. Agaian, Univ. of Texas at San Antonio (USA)

65790F A mesh-based robust digital watermarking technique against geometric attacks [6579-14] Y.-P. Huang, W. Yen, Y.-W. Chen, Tatung Univ. (Taiwan)

\section{SESSION 4 DATA HIDING}

$65790 \mathrm{G}$ Data hiding based on Fibonacci-Haar transform [6579-16]

F. Battisti, Univ. degli Studi Roma Tre (Italy); K. Egiazarian, Tampere Univ. of Technology

(Finland); M. Carli, A. Neri, Univ. degli Studi Roma Tre (Italy)

65790H A chaotic cipher Mmohocc and its security analysis [6579-17]

X. Zhang, City Univ. of New York (USA); L. Shu, Sichuan Univ. (China); K. Tang, City Univ. of New York (USA)

\section{SESSION 5 IDENTIFICATION SYSTEMS AND APPLICATIONS}

65790 Multi-level signature based biometric authentication using watermarking [6579-20]

E. Maiorana, P. Campisi, A. Neri, Univ. degli Studi Roma Tre (Italy)

$65790 \mathrm{~K}$ The problems of using ROC curve as the sole criterion in positive biometrics identification [6579-21]

Y. Du, Indiana Univ.-Purdue Univ. Indianapolis (USA); C.-I Chang, Univ. of Maryland, Baltimore County (USA)

65790M Secure access control to hidden data by biometric features [6579-23]

M. Cancellaro, M. Carli, Univ. of Roma Tre (Italy); K. Egiazarian, Tampere Univ. of

Technology (Finland); A. Neri, Univ. of Roma Tre (Italy)

65790N Log-polar-based framework for mobile vehicle tracking with road follower [6579-24]

P. B. Melnyk, R. A. Messner, Univ. of New Hampshire (USA)

\section{SESSION 6 IMAGE/VIDEO PROCESSING AND RETRIEVAL}

657900 Human visual-system-based image enhancement [6579-25]

E. J. Wharton, K. A. Panetta, Tufts Univ. (USA); S. S. Agaian, The Univ. of Texas at San Antonio (USA)

65790P Wavelet library for constrained devices [6579-26]

J. H. Ehlers, S. A. Jassim, Univ. of Buckingham (United Kingdom) 
POSTER SESSION

65790S A robust digital watermarking scheme by use of integral imaging technique [6579-30] D.-C. Hwang, H.-J. Lee, Kwangwoon Univ. (South Korea); D.-H. Shin, Dongseo Univ. (South Korea); E.-S. Kim, Kwangwoon Univ. (South Korea)

$65790 T$ Secure OFDM-UWB communication based on phase hopping [6579-31]

A. Neri, D. Blasi, P. Campisi, Univ. degli Studi di Roma Tre (Italy)

$65790 \mathrm{U}$ Quantifying image similarity using measure of enhancement by entropy [6579-32]

E. A. Silva, K. Panetta, Tufts Univ. (USA); S. S. Agaian, The Univ. of Texas at San Antonio (USA)

65790W Fourier phase domain steganography: phase bin encoding via interpolation [6579-13]

E. Rivas, The Univ. of Texas at San Antonio (USA)

65790X Exploiting sub-pixel edge detection methods with high-density sampling to provide .001 pixels rigid target localization [6579-35]

J. F. Gray, Univ. of New Orleans (USA)

Author Index 
Downloaded From: https://www.spiedigitallibrary.org/conference-proceedings-of-spie on 26 Apr 2023

Terms of Use: https://www.spiedigitallibrary.org/terms-of-use 


\title{
Conference Committee
}

\author{
Symposium Chair
}

John C. Carrano, Luminex Corporation (USA)

Symposium Cochair

Larry B. Stotts, Defense Advanced Research Projects Agency (USA)

Program Track Chair

Raghuveer M. Rao, Rochester Institute of Technology (USA)

Conference Chairs

Sos S. Agaian, The University of Texas at San Antonio (USA)

Sabah A. Jassim, University of Buckingham (United Kingdom)

Program Committee

Christopher R. Adams, University of Buckingham (United Kingdom)

David Akopian, The University of Texas at San Antonio (USA)

Patrick D. Baier, The George Washington University (USA)

Cesar Bandera, BanDeMar Networks (USA)

Chang Wen Chen, Florida Institute of Technology (USA)

Reiner Creutzburg, Fachhochschule Brandenburg (Germany)

Martin Dietze, 4G Systeme GmbH (Germany)

Yingzi Du, Indiana University-Purdue University Indianapolis (USA)

Frederic Dufaux, École Polyłechnique Fédérale de Lausanne (Switzerland)

Erlan H. Feria, College of Staten Island/CUNY (USA)

Phalguni Gupta, Indian Institute of Technology Kanpur (India)

Jacques Koreman, Norwegian University of Science and Technology

(Norway)

Maryline Maknavicius, Institut National des Télécommunications (France)

Alessandro Neri, Università degli Studi di Roma Tre (Italy)

Gilbert L. Peterson, Air Force Institute of Technology (USA)

Sonia Salicetti, GET/INT (France)

Xiyu Shi, University of Surrey (United Kingdom)

Pedro Soria-Rodriguez, CISSP (Spain)

Gregory B. White, Center for Infrastructure Assurance and Security (USA)

Session Chairs

1 Image/Video Compression

Erlan H. Feria, College of Staten Island/CUNY (USA) 
2 Network Issues

Sabah A. Jassim, University of Buckingham (United Kingdom)

3 Security of Media Objects

Frederic Dufaux, École Polytechnique Fédérale de Lausanne (Switzerland)

$4 \quad$ Data Hiding

Yo-Ping Huang, Tatung University (Taiwan)

5 Identification Systems and Applications

Salim Alsharif, University of South Alabama (USA)

$6 \quad$ Image/Video Processing and Retrieval

Sos S. Agaian, The University of Texas at San Antonio (USA) 